\title{
Phylogenetic and taxonomic position of the genus Wollea with the description of Wollea salina sp. nov. (Cyanobacteria, Nostocales)
}

\author{
Eliška KozlíKovÁ-ZapomĚlová ${ }^{1}$, Thomrat Chatchawan ${ }^{2}$, Jan KaŠTovskÝ ${ }^{3}$ \& Jiří \\ KOMÁREK $^{3,4, *}$
}

\author{
${ }^{1}$ Biology Centre of AS CR, Institute of Hydrobiology, Na Sádkách 7, CZ 37005 České Budéjovice, Czech Re- \\ public \\ ${ }^{2}$ Maejo University Phrae Campus, Mae Sai, Rong Kwang, 54140, Thailand \\ ${ }^{3}$ Department of Botany, Faculty of Science, University of South Bohemia, Branišovská 31, CZ-370 05 České \\ Budéjovice, Czech Republic \\ ${ }^{4}$ Institute of Botany AS CR and University of South Bohemia, Dukelská 135, CZ - 37982 Třeboň, Czech Re- \\ public; e-mail: Jiri.Komarek@ibot.cas.cz
}

\begin{abstract}
The taxonomic separation of the related heterocytous cyanobacterial genera Wollea and Anabaena is unclear according to traditional taxonomic features, as modern polyphasic approach has not yet been applied to compare them. However, comparison of the type species of these genera and their polyphasic analyses enable the separation of both generic entities. Definitions of their diacritical characters follow from the combination of their phylogenetic and morphological criteria. The concepts of Anabaena sensu stricto (particularly without planktic types with gas vesicles in cells - Dolichospermum) and Wollea, derived from their types are proposed in the article and their review is presented in the table. A new species from saltworks in southern Thailand, $W$. salina, is described.
\end{abstract}

Key words: Anabaena, Cyanobacteria, ecology, molecular analyses, morphology, polyphasic approach, taxonomy, Wollea

\section{INTRODUCTION}

The little known cyanobacterial genus Wollea is taxonomically classified in the vicinity of the wide, polymorphic and heterogeneous group of Anabaena-types, according to the modern combined genetic and morphological criteria (polyphasic approach). The morphological diacritical markers that determine taxa belonging to the genus Wollea are fasciculated trichomes (agglomerated usually in finger-like delimited colonies), widely oval akinetes, their position in isopolar filaments from both sides of the intercalary heterocytes, form of more or less barrel-shaped vegetative cells and \pm rounded conical apical cells. However, according to several authors (e.g., Kiselev from Hollerbach et al. 1953; KOMÁREK 1975), these characters are considered not to be taxonomically important, and are similar in a few populations of the type species of the genus Anabaena, An. oscillarioides. In principle, both genera (respecting concepts of the type species) contain similar morphological characters.

The genus Anabaena is very diverse, particu- larly with respect to molecular evaluation (16S rRNA gene sequences; ZAPOMĚLOVÁ et al. 2013, in litt.). From the traditional concept of Anabaena (Geitler 1932; Fritsch 1949; Hollerbach et al. 1953; Prescott 1962; BOURRELly 1970), the generic clades of Chrysosporum, Dolichospermum, Sphaerospermopsis and Trichormus have already been separated according to both genetic and morphological criteria (KoMÁreK \& ANAGNOSTIDIS 1989; RAJANIEMI et al. 2005a, b; KOMÁREK \& ZAPOMĚLOVÁ 2007, 2008; WACKLIN et al. 2009; ZAPOMĚLOVÁ et al. 2012; KомÁREK 2013). However, the part of the original genus Anabaena sensu stricto (particularly without planktic and aerotopated genera Dolichospermum and Sphaerospermopsis) is still heterogeneous according to phylogenetic analyses (HALINEN et al. 2008; ZAPOMĚLOvÁ et al. 2013, in litt.). The different Anabaena clades (following from the phylogenetic studies) can only be partially characterized by morphological markers, e.g., by the position and form of akinetes, form of vegetative cells, form of apical cells, etc., which have not yet been considered as taxonomically important. Another complication is that several strains, identified as Anabaena 
oscillarioides, are similar (both morphologically and genetically) to several strains of Wollea saccata, which is the type species of the genus Wollea (comp. GeITLER 1932, 1942; Drouet 1978; HindÁk 2008; KozHevnikov \& Kozhevnikova 2011; KomáreK 2013; and others). The problem is also that the strains isolated and identified by various authors as An. oscillarioides and used in the construction of later phylogenetic trees, occur in a few distant places in the phylogenetic scheme (Fig. $1)$. It is therefore difficult to exactly identify from this situation, which modifications (resp. clusters) of "Anabaena oscillarioides" correspond to the types of Anabaena or Wollea.

The type species of Wollea is not available in exsiccates. Only the typification of Anabaena according to the original material is possible, and can be morphologically indicated by study of the type slide of $A n$. oscillarioides (from Museum National d'Historie Naturelle - PC; cf. DrouET 1978). The results presented in this paper and meant to answer the problems stated above are:

(i) The type exsiccate of Anabaena oscillarioides (from PC) has been revised and the concept of the original genus Anabaena was derived.

(ii) The positions of strains morphologically identified as An. oscillarioides and distinguishable one from another according to molecular analysis (the $16 \mathrm{~S}$ rRNA gene sequencing) were determined in the phylogenetic tree, and the clade morphologically corresponding to the type of An. oscillarioides was determined.

(iii) Phylogenetic relations of cultures, preliminarily identified as various Wollea-strains (including the type species $W$. saccata) are described, and comparisons of the genus Wollea to different strains of "Anabaena oscillarioides" (with respect either to the type, or in the sense of the later authors) are presented.

(iv) The review of the genus Wollea is summarized in the table, respecting all material available (morphological descriptions and results from the $16 \mathrm{~S}$ rRNA gene sequencing).

(v) The taxonomic description of a new species of Wollea from halophilic habitats from the marine coasts of Petchaburi Province, Thailand, is presented.

\section{Methods}

Optical microscopy. The material used in this study was observed using Leitz Dialux 22 and Olympus BX51 microscopes up to $1000 \times$ magnification. Samples of $W$. salina were collected from artificial ponds in solar salterns at $13.30^{\circ} \mathrm{N}$ latitude and $100.07^{\circ} \mathrm{E}$ longitude in Petchaburi Province, Thailand, in November and December 2009 and cultured from the same soil samples on agarised BG11 medium (STANIER et al. 1971; with various salt concentrations) at $25^{\circ} \mathrm{C}$, light intensity of $28 \mu \mathrm{mol} \cdot \mathrm{m}^{-2} \cdot \mathrm{s}^{-1}$ and a light cycle of $12: 12$ light/ dark periods.
Molecular analysis. The biomass was harvested in the exponential growth phase by repeated centrifugation (centrifuge $\mathrm{Z}$ 233 MK-2; Hermle Labortechnik GmbH, Wehingen, Germany), during which the trichomes were washed several times by physiological solution $(\mathrm{NaCl}$ solution, concentration $1 \mathrm{~g}$ . $\left.\mathrm{L}^{-1}\right)$ to remove mucilaginous substances. The biomass samples were stored at $20^{\circ} \mathrm{C}$ until DNA extraction. DNA was extracted using the UltraClean (tm) Microbial DNA Isolation Kit (MO BIO Laboratories Inc., Carlsbad, CA, USA). The 16S rRNA gene and ITS region were amplified using primers 16S27F (5'-AGAGTTTGATCCTGGCTCAG-3') and 23S30R (5'- CTTCGCCTCTGTGTGCCTAGGT-3') (TATON et al. 2003). Amplification was carried out as follows: one cycle of $5 \mathrm{~min}$ at $94^{\circ} \mathrm{C} ; 10$ cycles of $45 \mathrm{~s}$ at $94{ }^{\circ} \mathrm{C}, 45 \mathrm{~s}$ at $57^{\circ} \mathrm{C}$, and 2 min at $72{ }^{\circ} \mathrm{C} ; 25$ cycles of $45 \mathrm{~s}$ at $94^{\circ} \mathrm{C}, 45 \mathrm{~s}$ at $54{ }^{\circ} \mathrm{C}$, and 2 min at $72{ }^{\circ} \mathrm{C}$; followed by a final elongation step of $7 \mathrm{~min}$ at $72{ }^{\circ} \mathrm{C}$. The PCR product was used as a template for sequencing with primers $16 \mathrm{~S} 27 \mathrm{~F}$ (TATON et al. 2003) CYA781F (a) (5'-AATGGGATTAGATACCCCAGTAGTC-3') (NüBEL et al. 1997), K6 (5'-GACGGGCCGGTGTGTACA-3'), which is the reverse complement of Primer14 of Wilmotte et al. (1993), and K8 (5'-AAGGAGGTGATCCAGCCACA-3') (Flechtner et al. 2002). Partial sequences of the 16S rRNA gene (1369 bp) were aligned using the program BioEdit version 7.0.9.0 (HALl 1999) and the alignment was edited manually. Phylogenetic trees were constructed by maximum-likelihood (ML) maximum parsimony (MP) and neighbour-joining (NJ) (SAITOU \& NEI 1987) algorithms in the program PAUP* version 4.0b10 (SwOFForD 2003). The topology for the phylogenetic tree was derived from ML. The GTR $+\mathrm{I}+\mathrm{G}$ evolutionary model of substitution was found for the best fit to the data using ModelTest 3.7 (PosADA 2008). The parameters (base frequencies, rate matrix of substitution types and shape of gamma distribution) were estimated from the data. 100 and 1000 bootstrap replicates were performed for ML and NJ analysis, respectively. Nucleotide sequences were deposited at GenBank under the accession numbers (comp. Tab. S1).

\section{Results}

\section{Separation of the type species of the genera Ana-} baena and Wollea

The type species of the genus Anabaena, An. oscillarioides, occurs in literature in several concepts, differing in the form of akinetes (cylindrical up to oval, widely oval to almost spherical), situated either side of the heterocytes. However, the correct concept must be derived from the type specimen (exsiccate) of An. oscillarioides, which is deposited in the PC Museum collection in Paris. This material was microscopically studied with the following results (Fig. 2): The exsiccate, designated MNHN-PC-PC0558651, contains a natural sample with a macroscopic blue-green mat of probably one morphologically homogeneous colony of densely entangled, joined, \pm straight or mostly irregularly flexuous, not branched and not ensheated filaments or their fragments. Trichomes were composed of wider parts (segments) with barrel-shaped up to almost spherical cells, 4-6.5 $\mu \mathrm{m}$ wide, transient sometimes immediately 


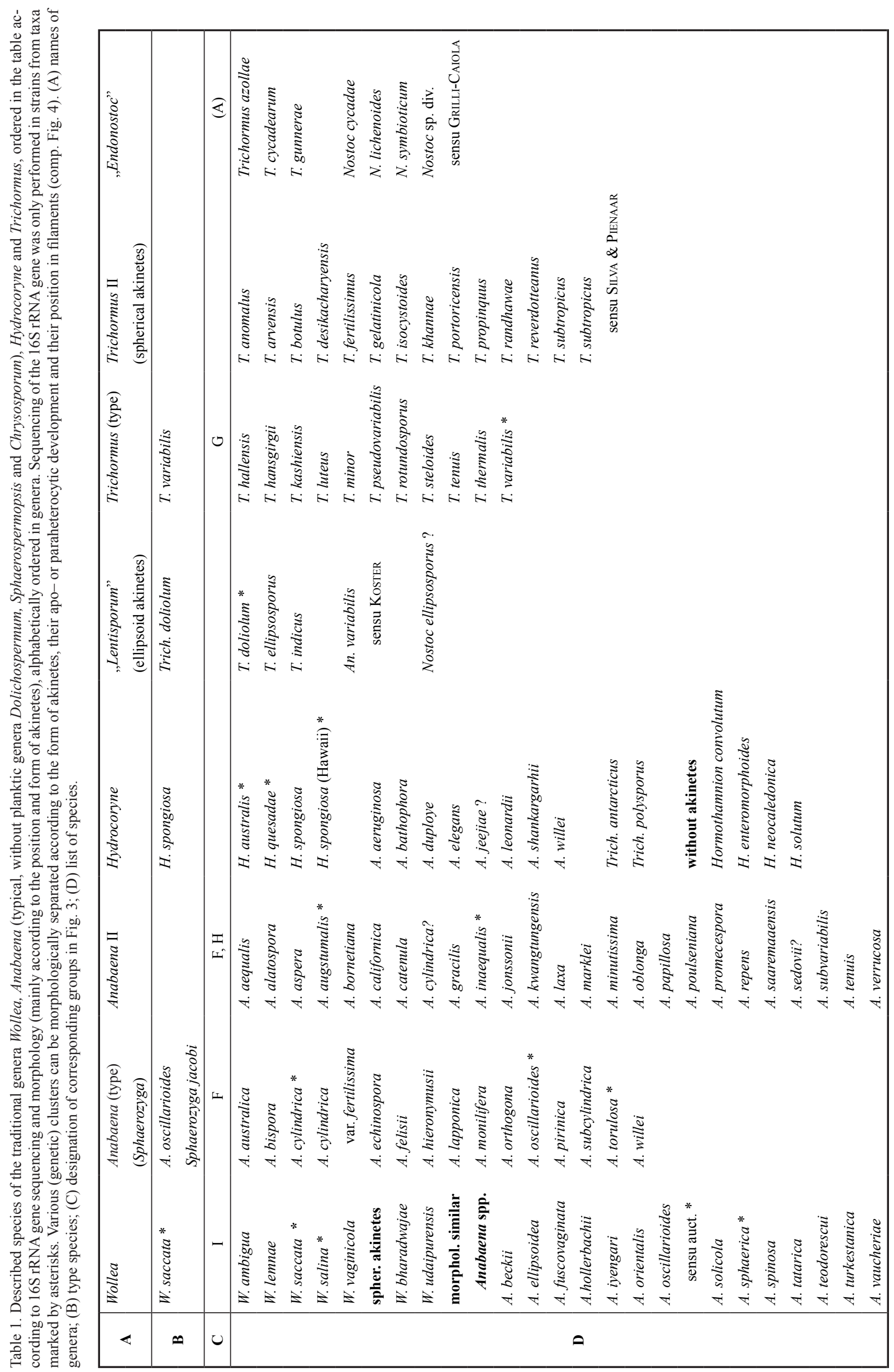




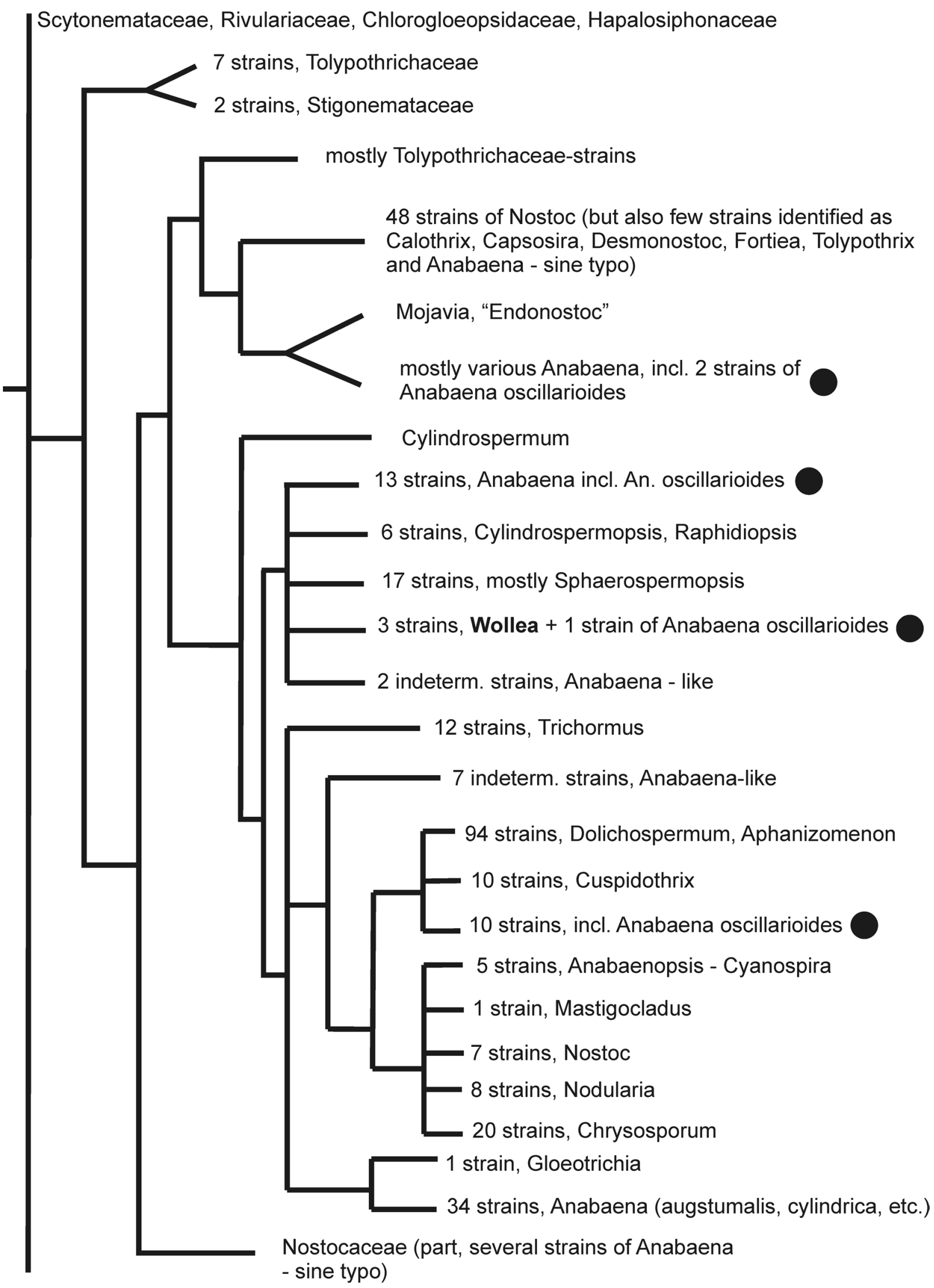

Fig. 1. Simplified scheme of probable relations, derived from 16S rRNA gene sequences of more than 400 strains of nostocalean-heterocytous cyanobacteria and morphological similarity. The names of analyzed strains were accepted according to identifications in GenBank and respecting the isolators' determination and collections, but names in our scheme were already modified according to the modern system (KOMÁREK et al. 2014) as much as possible. 

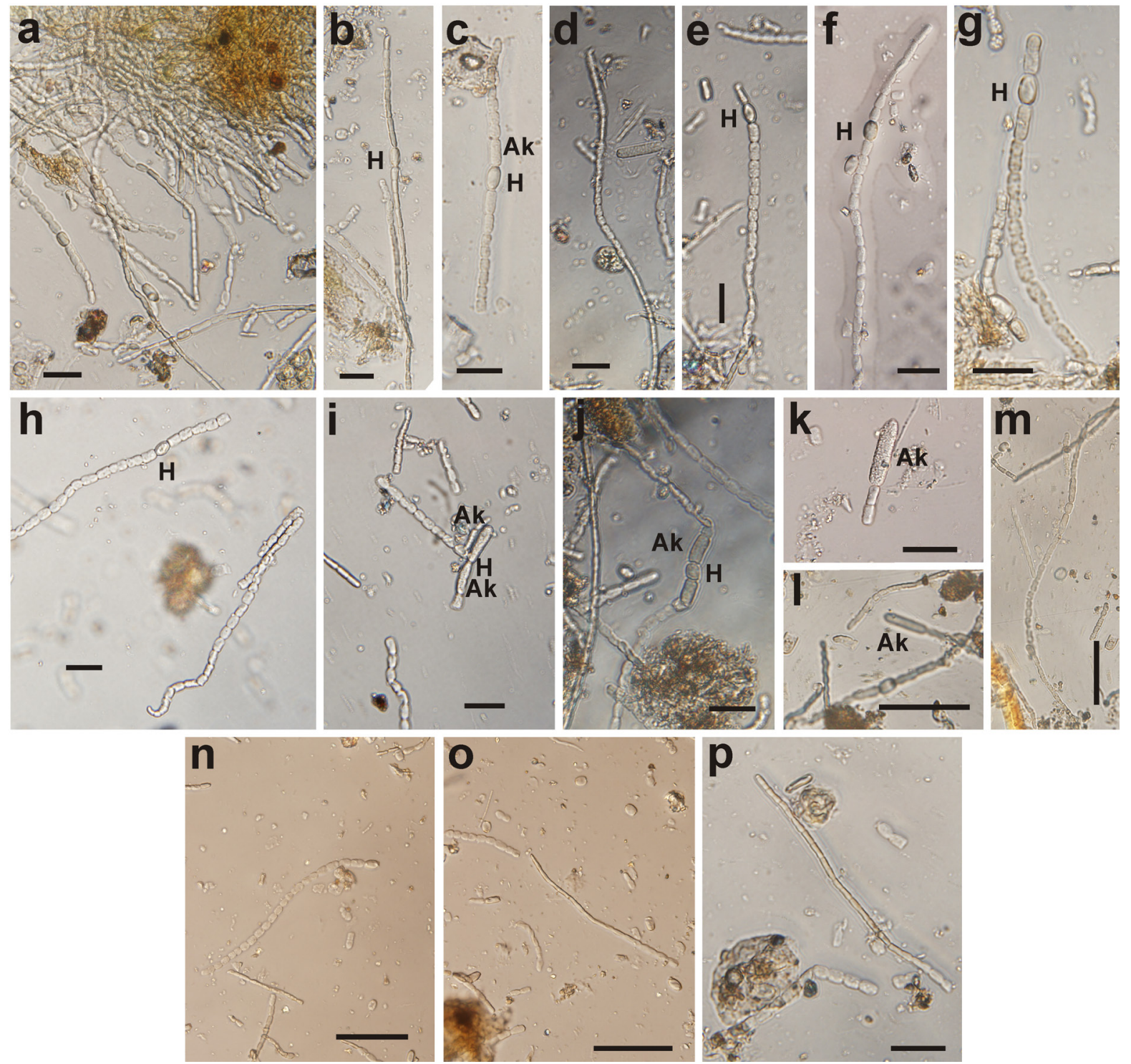

Fig. 2. Specimens from the type strain (exsiccate) of Anabaena oscillarioides, PC Museum Paris; (Ak) akinetes, (H) heterocytes. Scale bars $20 \mu \mathrm{m}$.

to the narrowed parts with longer (up to $\pm 9.5 \mu \mathrm{m}$ ) and only 2-3.8 $\mu \mathrm{m}$ wide cells (probably partly deformed by desiccation). In filaments, intercalary, \pm rectangular up to oval heterocytes $(\mathrm{H})$ with rounded ends occurred, $\pm 8-13 \times(3) 7-8 \mu \mathrm{m}$, solitary developed, never found more together. Mostly two (three) intercalary heterocytes appeared in one trichome, being always slightly wider than vegetative cells. Apical cells were usually conical with rounded ends, rarely (especially in narrow trichomes) cylindrical and rounded (Fig. 2b-g). Filaments were irregularly situated in clusters in mats, only in small parts of the thallus was there a tendency towards parallel arrangement of filaments. Akinetes (Ak) were developed and joined at both sides of the heterocytes, and occurred solitary or less frequently in twos (exceptionally 3 in rows). Young akinetes had a \pm barrel-shaped form, but later transformed to long cylindrical with rounded ends, up to $28 \times \pm 7.5 \mu \mathrm{m}$ (Fig.
$2 \mathrm{i}-1)$. The genetic homogeneity of the studied material was not proven (as molecular analyses were impossible due to the old, desiccated and preserved state of the type exsiccate). However, the morphologically transient forms possibly indicate the presence of only one variable genotype in the exsiccate. The dimensions can be slightly deformed after long preservation in a dried state in the herbarium.

From the morphological analysis of this type specimen, it follows that to the autapomorphic features of the type species of the genus Anabaena must be incorporated \pm cylindrical akinetes (only with rounded ends), developing adjacent to heterocytes from both sides. Because various isolated strains identified as "Anabaena oscillarioides" occur in several places of the phylogenetic tree (Figs 1, 3; black points), it is necessary to identify the cluster corresponding with the type specimen, without respect to the previous identi- 
fication of strains. The strains from groups " $D$ ", "F" or " $\mathrm{H}$ " in Fig. 3 were designated as "An. oscillarioides", but only group "F" contains a cluster of typical benthic Anabaena species with cylindrical akinetes joined to the heterocytes and corresponds therefore morphologically to the type material of Anabaena. On the other hand, the types similar to An. oscillarioides with akinetes adjacent to the heterocytes from both sides, but with a distinctly oval shape and arranged usually in rows of (1)2-(3)5 belong rather to another group (I), which corresponds with high probability to the genus Wollea (Figs 3,4; Table 1). Based on this point of view, "Anabaena oscillarioides" sensu Hollerbach et al. (1953), KomÁreK (1975), SieminSKa (1953) and partly also KomÁREK (2013), does not morphologically belong to the typical An. oscillarioides and must be reclassified to the genus Wollea (cf. also HiNDÁK 2008; KozHevnikov \& Kozhevnikova 2011; and others). On the contrary, only types with cylindrical akinetes, which are adjacent to heterocytes evidently belong to the genus Anabaena (Fig. 4 - group F, Table 1). The position of species with cylindrical akinetes distant from heterocytes must be revised in future.

The type exsiccate of the genus Wollea does not exist, therefore the description of BORnET \& FlaHAUlT (1888 - starting point of the genus Wollea) must be considered as the type of this genus. The type species, W. saccata, and all other related species are characterized not only by tubular colonies with common sheaths (diacritical character), but also by \pm straight trichomes, organized \pm parallel and tightly in colonies, by oval up to widely oval or almost spherical akinetes situated facultatively at heterocytes up to 5 in short rows, and often by filaments growing in \pm fascicles, mainly in submersed habitats. According to this definition, to the genus Wollea belong W. saccata (type species), W. ambigua, W. bharadwajae, W. lemnae, W. udaipurensis, $W$. vaginicola and probably numerous other species, originally described inside the genus Anabaena (cf. KomÁreK 2013; Table 1). Although this group is not well supported by the 16S rRNA gene analysis (Fig. 3 ), the taxa with morphologically corresponding types are more or less situated and located close to each other and can be designated ad interim in one generic entity.

\section{Description of Wollea salina}

The strain "Liew", isolated from Petchaburi Province, Thailand, morphologically corresponded to the characteristics of the genus Wollea and appeared in the vicinity of other Wollea strains on the basis of the 16S rRNA gene phylogeny (Fig. 3, group "I", strain LIEW=CCALA 1091). The genus Wollea does not represent a clearly defined phylogenetic cluster. However, because it is not connected and does not correspond to the similar genus Anabaena (in the typical concept, group "F"), we classify it separately. We describe therefore also our strain from salines near Petchaburi as a new species, Wollea salina sp. nov. (Fig. 5):
Wollea salina Chatchawan, Kozlíková, Komárek et KAšTovskÝ sp. nov. (Figs 5, 6)

Description: Colonies are filamentous, with densely and parallel packed trichomes, enveloped by colourless, delimited distinct slime, blue-green, forming rough mats in strong development. Trichomes very rarely \pm solitary (initial stages), usually in fascicles, straight, waved to slightly curved, with the same width along the whole length, unbranched, constricted at crosswalls, with very indistinct own sheaths, or without them. Cells barrel-shaped to cylindrical, blue-green, \pm isodiametric to slightly longer than wide, $1.5-2 \times \pm 1.6$ $\mu \mathrm{m}$ wide, apical cells rounded-pointed. Heterocytes intercalary, oval to barrel-shaped, very slightly wider than vegetative cells. Young akinetes cylindrical, later oval, elongate, larger than the vegetative cells, situated to both sides of a heterocyte, solitary, rarely a few in short rows, smooth at the surface, with a slightly brown exospore, $7-10 \times 3.2-4.5 \mu \mathrm{m}$.

Etymology: specific name according to the character of habitat.

Type locality: Thailand, Petchaburi Province, in Ban Leam District, surrounded by mangrove forest, about $5 \mathrm{~m}$ above sea level.

Habitat: on wet salty soils, sometimes slightly covered by shallow layer of water (in salines, 0-35 ppt).

Iconotype: Fig. 5.

Holotype: CCALA 1091.

\section{Discussion}

The genus Wollea was described originally based on morphological characters and it is evidently different from the genus Anabaena also according to molecular criteria. In spite of the fact that it does not form a clearly delimited phylogenetic cluster based on the 16S rRNA gene, it can be considered ad interim as a special generic cluster (cf. Fig. 3). It is characterized by uniseriate trichomes, which are isopolar, \pm parallel situated within mucilaginous colonies, sometimes in close fascicles which can be delimited by a \pm firm periderm; the colonies have "finger-like" or \pm amorphous appearance of colonies. The cells are spherical, barrel-shaped up to cylindrical, of the same morphology in one filament, the end cells are rounded or conical-rounded. The cells have sometimes granular content, without gas vesicles. Heterocytes are intercalary, usually solitary, spherical or barrel-shaped, of the same width or slightly wider as the vegetative cells. Akinetes are obligatorily situated from both sides of heterocytes, solitary or up to 5 in a row, widely oval, ovoid or up to subspherical. All species live usually in unpolluted freshwaters, rarely in slightly eutrophic or saline waters (BORNET \& Flahault 1888; KomÁrek 2013). The type species is Wollea saccata [Wolle] Bornet et Flahault 1888 [pre-starting-point syn. $=$ Sphaerozyga saccata WOLLE 
1880]. This cluster is not very well supported by molecular analysis of the 16S rRNA gene, however, it is evidently different from Anabaena (Fig. 3, cluster I of Wollea vs. cluster F of Anabaena) and its phylogenetic position will probably have to be elucidated by a future multilocus sequence analysis. The species, which probably belong to this genus (compared with autapomorphic features), are listed in Table 1. The currently described Wollea species with their diagnostic features are included in Figs 5, 6, 7d.

The genus Anabaena was found still very heterogeneous in the traditional sense, and only the cluster "F" (Fig. 3), which contains the type species, represents the correct concept of this genus.

The genus Wollea (group "I") is therefore distinguishable from the polyphyletic genus Anabaena by phylogenetic position as well as morphologically, but unconvincingly (with small bootstrap support) from the rest of the group of Sphaerospermopsis, Cylindrospermopsis and "Anabaena"- like group (Fig. 3, groups "J", "K", "L"; not forming a distinct separate, delimited phylogenetic clade). The diacritical autapomorphic characters of Wollea are the oval up to almost spherical akinetes, developing closely from both sides of intercalary heterocytes; this phenotypic difference is similar, as, e.g., in Sphaerospermopsis, but the morphology of akinetes is different. Another yet unclear and unstable morphological marker is the parallel agglomeration of trichomes within enveloping mucilage in elongated, slimy colonies, sometimes distinctly delimited. The genus Hormothamnion is morphologically similar to Wollea and differs only by the total absence of akinetes, which is a problematic feature (cf. KOMÁREK 2013) and requires further revisions.

The position of Wollea and its unclear relations to other related genera (genetically Sphaerospermopsis and Cylindrospermopsis, morphologically Anabaena, Trichormus, Hydrocoryne and "Lentisporum") is clear in Fig. 3 and Table 1. This documentation also shows the wide heterogeneity of the whole traditional genus Anabaena. The possible phenotypic classification of the described taxa from this clade according to our first revision is reviewed in Table 1 and Fig. 4. The morphological definition of the currently known heterogeneous genus Anabaena and the separation of the similar genus Wollea is shown. The revised genus Anabaena must be defined according to the type exsiccate of $A n$. oscillarioides (cf. Figs 2-4, Table 1). However, the autapomorphic (and partly ecological) criteria could also be applied here to help to separate the different clades and clusters.

\section{ACKNOWLEDGEMENT}

The authors thank the PC Museum in Paris (Dr. Reviers) for the possibility to study the type material of the genus Anabaena, deposited in the Herbaria of this Institution. We are also thankful to Mrs. Dana Švehlová (Institute of Botany of AS CR) for technical help. The study was elaborated under the support of grants GA CR P506/12/1818, P504/14/18067S and 15-11912S. The language correction has been made by Dr. Keith Edwards.

\section{REFERENCES}

Bornet, E. \& Flahault, C. (1886-1888): Revision des Nostocacées heterocystées. - Annales des Sciences Naturelles, 7 ser., 3: 323-381, 4: 343-373, 5: 51129, 7: 171-262.

Bourrelly, P. (1970): Les algues d'eau douce. III. - 512 pp., N. Boubée \& Cie., Paris.

Chatchawan, T.; Peerapornpisal, Y. \& KomáreK, J. (2011) : Diversity of cyanobacteria in man-made solar saltern, Petchaburi Province, Thailand - a pilot study. - Fottea 11: 203-214.

Drouet, F. (1978): Revision of the Nostocaceae with constricted trichomes. - 258 pp., Beih. Nova Hedwigia, Cramer Vaduz.

Flechtner, V. R.; Boyer, S.L.; Johansen, J.R. \& DeNoble, M.L. (2002): Spirirestis rafaelensis gen. et sp. nov. (Cyanophyceae), a new cyanobacterial genus from arid soils. - Nova Hedwigia 74: 1-24.

Fritsch, F.E. (1949): The genus Anabaena, with special reference to the species recorded from India and from adjacent Asiatic mainland. - Journal of the Indian Botanical Society 28: 135-161.

Geitler, N.L. (1932): Cyanophyceae. - In: Rabenhorst's Kryptogamenflora von Deutschland, Österreich und der Schweiz 14. - 1196 pp., Akad. Verlagsges., Leipzig.

Geitler, L. (1942): Schizophyta (Klasse Schizophyceae). - In: Engler, A. \& Prantl, K. (eds): Natürliche Pflanzenfamilien 1b. -232 pp., Duncker \& Humblot, Berlin.

Guarrera, S.A. \& Echenique, R.O. (1998): Cyanophyta: Hormogonophycideae. - In: GuARrera, S.A.; GAmUNDI DE Amos, I. \& MatTeri, C.M. (eds.): Flora Criptogámica de Tierra del Fuego, Vol. 1,2. - 92 pp., Buenos Aires.

Halinen, K.; Fewer, D. P.; Sihvonen, L. M.; Lyra, C.; Erone, E. \& Sivonen, K. (2008): Genetic diversity in strains of the genus Anabaena isolated from planktonic and benthic habitats of the Gulf of Finland (Baltic Sea). FEMS Microbiology Ecology 64: 199-208.

HALl, T.A. (1999): BioEdit: a user-friendly biological sequence alignment editor and analysis program for Windows 95/98/NT. - Nucleic Acids Symposium Series 41: 95-98.

HindÁk, F. (2008): Colour atlas of Cyanophytes. - 253 pp., Veda, Bratislava.

Hollerbach, M.M.; Kosinskaja, E.K. \& Poljanskij, V.I. (1953): Sinezelenye vodorosli. [Blue-green algae]. - Opredel. Presnovod. Vodoros. SSSR 2. - 652 pp., Izdat. „Sovetskaja nauka“, Moskva.

KomÁreK, J. (1975): Blaualgen aus dem Naturschutzgebiet „Řežabinec“ bei Ražice. - Nova Hedwigia 26: 601-643.

KomÁreK, J. (2013): Cyanoprokaryota - 3. Teil / 3rd Part: Heterocytous Genera. - In: BÜDEL, B.; GÄrTNER, G.; Krienitz, L. \& Schagerl, M. (eds): Süswasserflora von Mitteleuropa (Freshwater Flora of Central Europe) 19/3. - 1130 pp., Springer Spektrum, Berlin -Heidelberg.

KomÁreK, J. \& AnAgnostidis, K. (1989): Modern approach to the classification system of cyanophytes 4 - Nostocales. - Algological Studies 56: 247-345.

KomÁreK, J. \& ZAPOMĚLovÁ, E. (2007): Planktic morphospecies of the cyanobacterial genus Anabaena $=$ subg. Dolichospermum - 1. part: coiled types. - Fottea 7: 


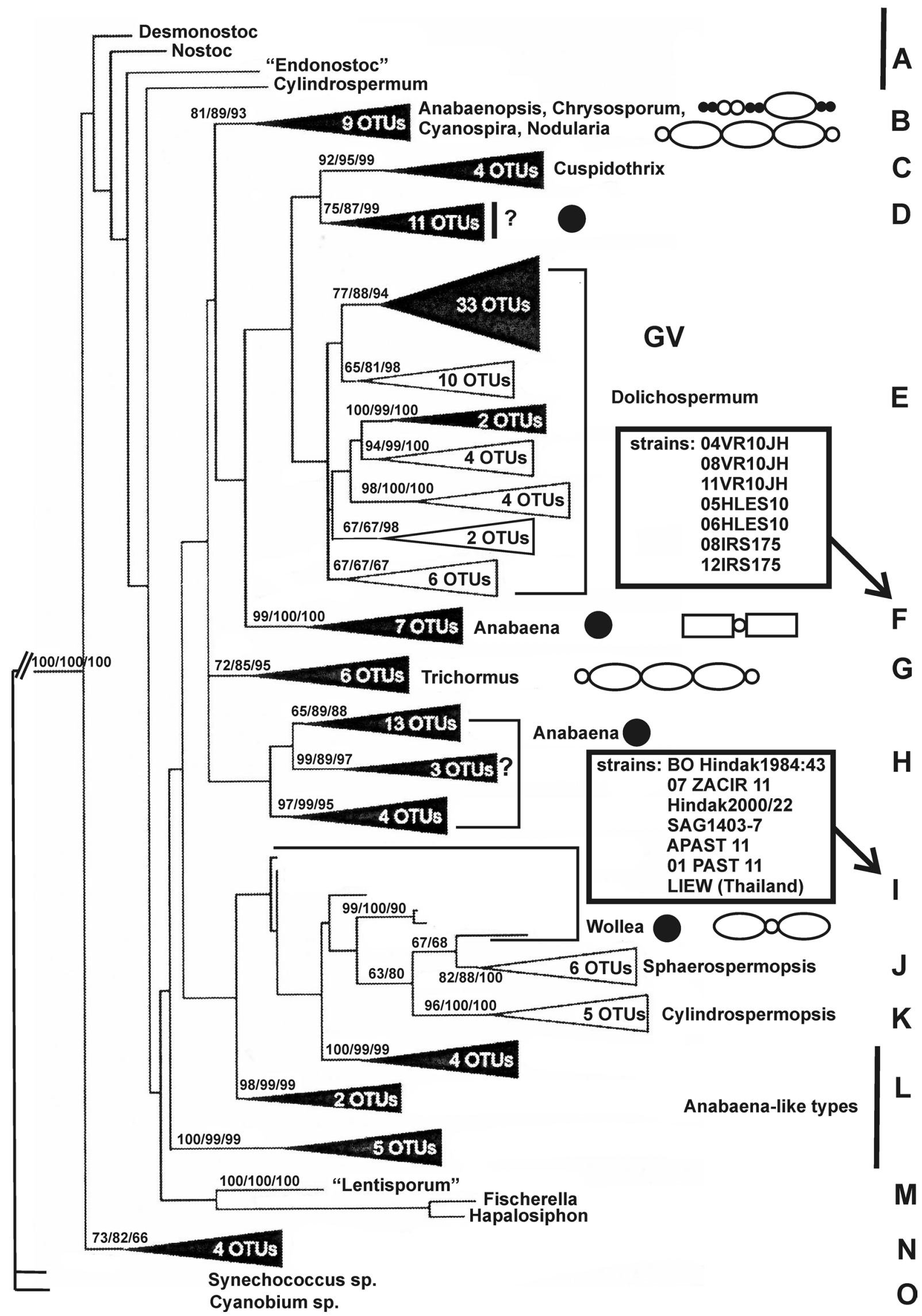

Fig. 3. Phylogenetic tree including the 16S rRNA gene sequences (1369 bp) of 72 Anabaena strains. Bootstrap values are given in the following order: ML/MP/ NJ. The groups A-K do not represent phylogenetic clusters and correspond only to the identification of discussed groups in the text. The clusters, containing the strains designated as "Anabaena oscillarioides", are marked by black points. The generic names are modified according to the most modern system (KomÁREK et al. 2014). The group (in this case = cluster) "F" contains An. oscillarioides strains morphologically corresponding to the type strain (comp. Fig. 2); (GV) obligatory occurrence of gas vesicles in cells. 


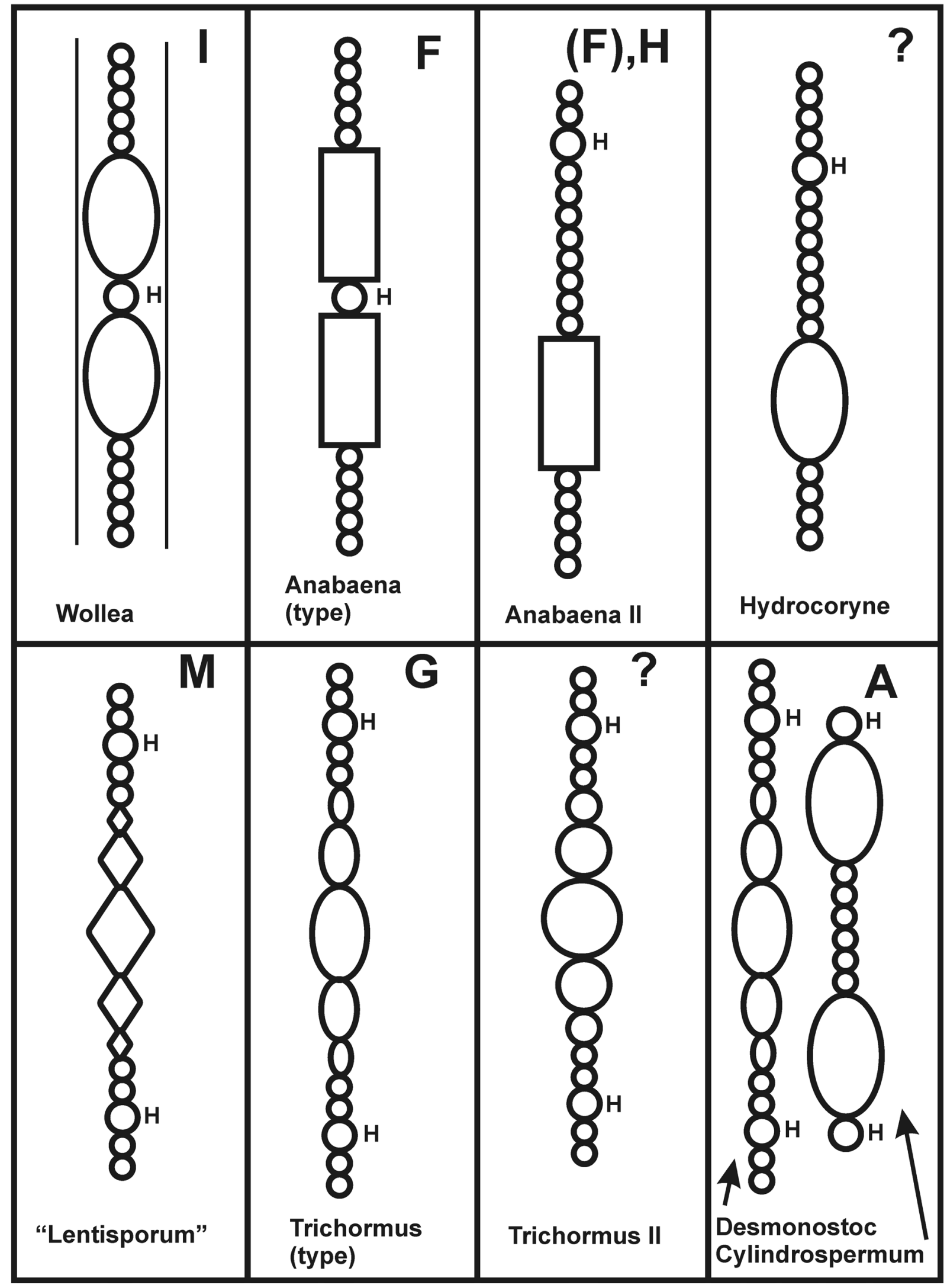

Fig. 4. Schematic modes of akinete forms and akinete arrangements in relation to the groups from Fig. 3 and Table 1. The type I corresponds with the genus Wollea. $(\mathrm{H})$ position of heterocytes. 

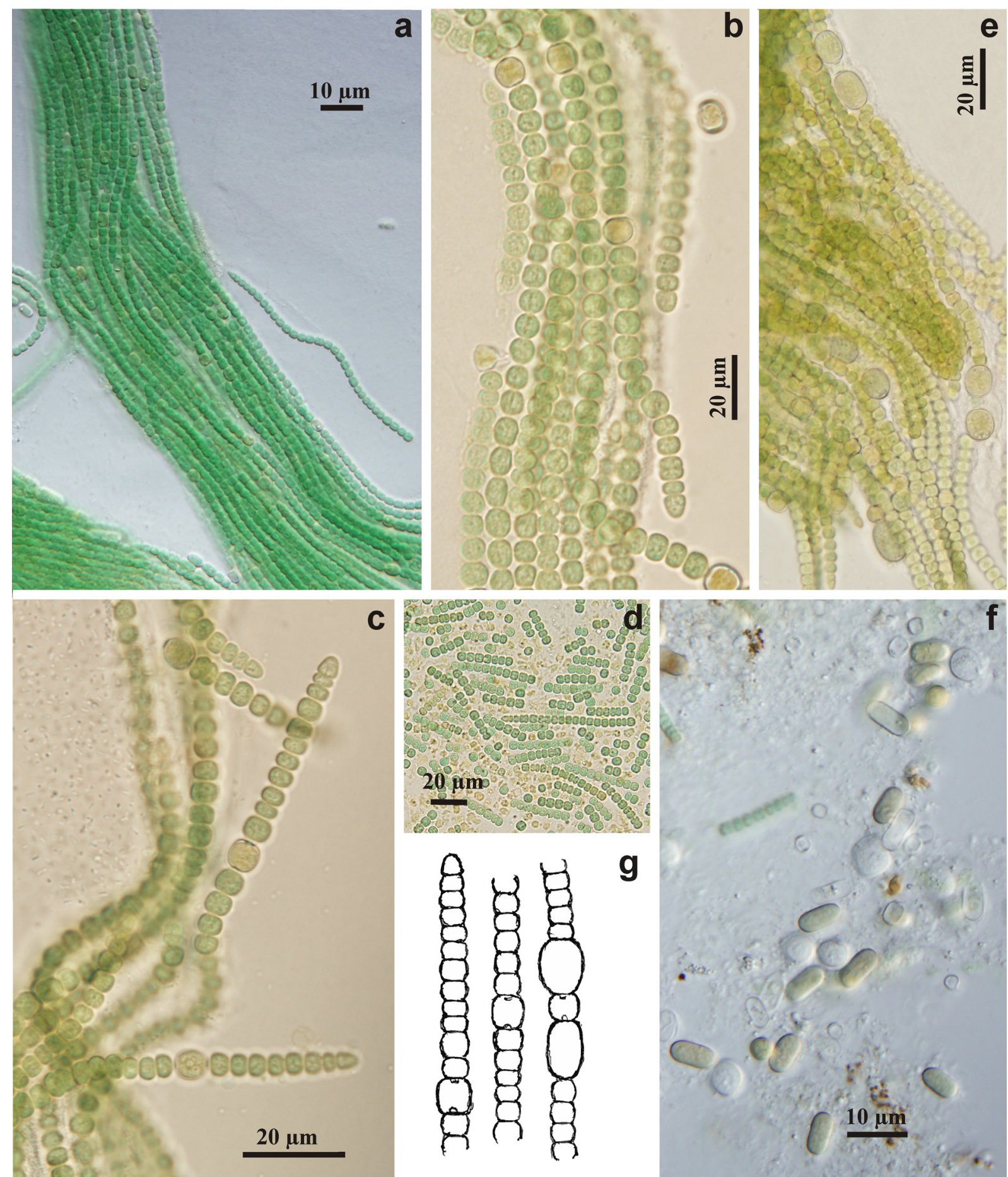

g

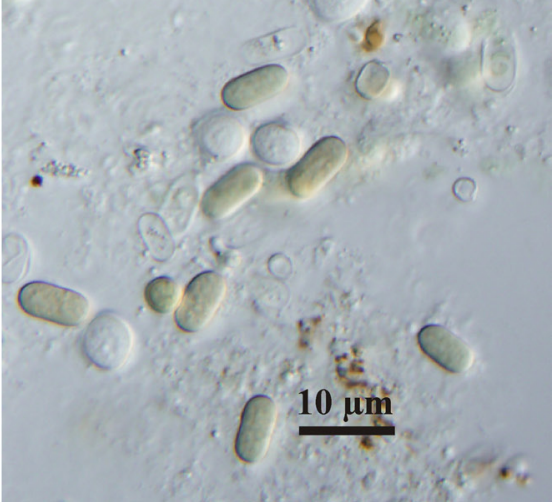

Fig. 5. Wollea salina sp. nov., type figures: (a-b) fascicles of filaments from natural material; (c) detail of cells and terminal cells; (d) hormogonia; (e) trichomes with akinete formation; (f) liberated unripened akinetes; (g) detail of cells, terminal cells and akinetes (a and f from ChatchaWAn et al. 2011). 



Fig. 6. Examples of main Wollea species, derived from illustrations of previous authors: Wollea saccata (type species of Wollea), (a) after Wolle from GeITLER 1932, (b) after BourRelly 1970, (c) after HindÁK 2008; Wollea vaginicola: (d) after TiwARI \& PANDEy 1976, (e) after GuARRERA \& EChenique 1998; Wollea ambigua: (f) after Tiwari \& PANDey 1976, (g) after Rao from Fritsch 1949; Wollea bharadwajae: (h) after Singh 1942. 

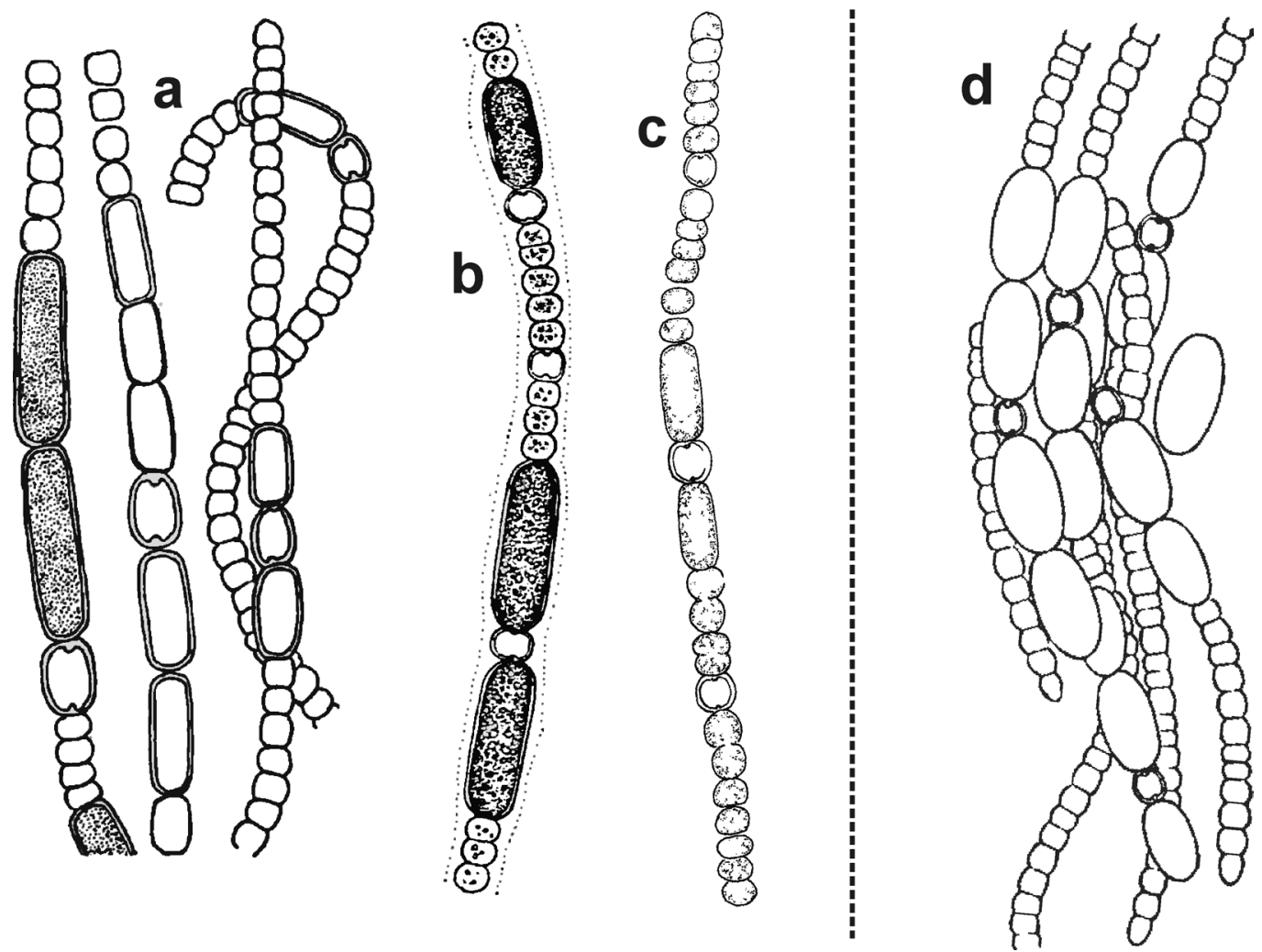

Fig. 7. Correct concepts of Anabaena oscillarioides: (a) after PrescotT 1962; (b) after SKUJA 1934; (c) after GuarRera \& EcheNIQUE 1998; in comparison with the concept of КомÁREK 1975 (d), probably corresponding to Wollea saccata.

$1-31$.

KoMÁReK, J. \& ZAPOMĚLovÁ, E. (2008): Planktic morphospecies of the cyanobacterial genus Anabaena $=$ subg. Dolichospermum - 2. part: straight types. - Fottea 8: 1-14.

KomáreK, J.; Kaštovskí, J.; Mareš, J. \& Johansen, J.R. (2014): Taxonomic classification of cyanoprokaryotes (cyanobacterial genera) 2014, using a polyphasic approach. - Preslia 86: 295-335.

Kozhevnikov, I.V. \& Kozhevnikova, N.A. (2011): Phylogenetic and morphological evaluation of Wollea saccata (Nostocales, Cyanobacteria) isolated from the Yenissei River basin (Eastern Siberia, Russia). Fottea 11: 99-106.

Nübel, U.; Garcia-Pichel, F. \& Muyzer, G. (1997): PCR primers to amplify $16 \mathrm{~S}$ rRNA genes from cyanobacteria. - Applied and Environmental Microbiology 63: $3327-3332$.

PosadA, D. (2008): ModelTest: phylogenetic model averaging. - Molecular Biology and Evolution 25:1253-6.

Prescott, G.W. (1962): Algae of the Western Great Lakes area. $2^{\text {nd }}$ ed. -977 pp., W.M. C. Brown Co., Dubuque, Iowa.

Rajaniemi, P.; Hrouzek, P.; Kaštovská, K.; Willame, R.; Rantala, A.; Hoffmann, L.; Komárek, J. \& SivoNEN, K. (2005a): Phylogenetic and morphological evaluation of the genera Anabaena. Aphanizomenon, Trichormus and Nostoc (Nostocales, Cyanobacteria). - Internatational Journal of Systematic and Evolutionary Microbiology. 55: 11-26.

Rajaniemi, P.; KomÁrek, J.; Hrouzek, P.; Willame, R.; KaštovskÁ, K.; Hoffmann, L. \& Sivonen, K. (2005b):
Taxonomic consequences from the combined molecular and phenotype evaluation of selected Anabae$n a$ and Aphanizomenon strains. - Algological Studies 117: 371-391.

Saitou, N. \& NeI, M. (1987): The neighbor-joining method: a new method for reconstructing phylogenetic trees. - Molecular_Biology and Evolution 4: 406-425.

SiemińsKa, J. (1953): Anabaena scheremetievi ElEnK. w Jeziorze Rożnowskim. - Acta Societatis Botanicorum Poloniae 22: 187-201.

SingH, R.N. (1942): Wollea bharadwajae sp. nov. and its auto-ecology. - Annals of Botany 6: 593.

SkujA, H. (1948): Taxonomie des Phytoplanktons einiger Seen in Uppland, Schweden. - Symbolae Botanicae Upsalienses 9, 3:1-399.

Stanier, R.Y.; Kunisawa, R. Mandel, M. \& Cohen-Bazire, G. (1971): Purification and properties of unicellular blue-green algae (Order Chroococcales). - Bacteriological Reviews 35: 171-205.

Swofford, D. L. (2003): PAUP*. Phylogenetic Analysis Using Parsimony (*and other methods). Version $4 \mathrm{~b} 10$. - Sunderland, MA: Sinauer Associates.

Taton, A.; Grubisic, S.; Brambilla, E.; De Wit, R. \& WilmоттE, A. (2003): Cyanobacterial diversity in natural and artificial microbial mats of Lake Fryxell (McMurdo dry valleys, Antarctica) - A morphological and molecular approach. - Applied and Environmental Microbiology 69: 5157-5169.

Tiwari, G.L. \& PANDEY, R.S. (1976): On the morphology and nitrogen fixation in Nodularia harveyana (Thwaites) Thuret, a new records from India.- Phycos 15: 5963. 
Wacklin, P.; Hoffmann, L. \& KomÁrek, J. (2009): Nomenclatural validation of the genetically revised cyanobacterial genus Dolichospermum (Ralfs ex Bornet et Flahault) comb. Nova. - Fottea 9: 59-64

Wilmotte, A.; Van der Auwera, G. \& De Wachter, R. (1993): Structure of the $16 \mathrm{~S}$ ribosomal RNA of the thermophilic cyanobacterium Chlorogloeopsis HTF (“Mastigocladus laminosus HTF") strain PCC7518, and phylogenetic analysis. - FEBS Letters 317: 96100.

Zapomělová, E.; Mareš, J.; Lukešová, A.; Skácelová, O.; ŘehÁKovÁ, K. \& Kust, A. (2013): Extensive polyphyly of non-gas-vacuolate Anabaena species (Nostocales, Cyanobacteria) - a challenge for modern cyanobacterial taxonomy. - In: Book of abstracts, Proc. of the 19th Symposium of IAC. - p. 51, Cleveland, USA.

ZapomĚlová, E.; SKácelová, O.; Puman, P.; Kopp, R. \& JANEČEK, E. (2012): Biogeographically interesting planktonic Nostocales (Cyanobacteria) in the Czech Republic and their polyphasic evaluation resulting in taxonomic revisions of Anabaena bergii Ostenfeld 1908 (Chrysosporum gen. nov.) and A. tenericaulis Nygaard (Dolichospermum tenericaule comb. nova). - Hydrobiologia 698: 353-365.

Supplementary material

the following supplementary material is available for this article:

Table S1. List of all strains, used to the construction of the tree in Fig. 3, with their accession numbers in GenBank and localities of origin.

This material is available as part of the online article (http://fottea.czechphycology.cz/contents)

(C) Czech Phycological Society (2016)

Received August 23, 2015

Accepted December 21, 2015 